\title{
An Exploration of Giving Among Gay Male College Alumni
}

\author{
Alex Vervoort ${ }^{1}$, Marybeth Gasman ${ }^{2}$ \\ ${ }^{1}$ Teachers College, Columbia University, USA \\ ${ }^{2}$ University of Pennsylvania, USA \\ Correspondence: Marybeth Gasman, University of Pennsylvania, USA
}

Received: January 12, 2016 Accepted: February 18, $2016 \quad$ Online Published: March 14, 2016

doi:10.11114/jets.v4i5.1298 URL: http://dx.doi.org/10.11114/jets.v4i5.1298

\begin{abstract}
This study explores the influence of sexual orientation and race on college alumni giving. The authors use qualitative methods, interviewing alumni at one university in the Northeast. They also provide recommendations for fundraising and alumni practitioners as well as recommendations for those scholars interested in student identity, fundraising, alumni giving, and campus climate.
\end{abstract}

Keywords: gay male students, alumni giving, fundraising, campus climate

\section{An Exploration of Giving Among Gay Male College Alumni}

The connection between a positive student experience and charitable giving among non-traditional donors has gained the interest of prominent scholars (e.g., Clotfelter, 2003; Gasman \& Anderson-Thompkins, 2003; Gasman \& Bowman, 2013b), and a handful of colleges and universities across the country (e.g., Columbia University, University of Pennsylvania, Cornell University). One population of alumni that has gained more attention recently is alumni that identify as lesbian, gay, bisexual, transgender, and queer (LGBTQ) (Garvey \& Drezner, 2013a; Garvey \& Drezner, 2013b). Despite this attention, research focused specifically on LGBTQ college alumni remains significantly understudied in the realm of philanthropy (Garvey \& Drezner, 2013b). The studies that have emerged (e.g., Garvey \& Drezner, 2013a) around LGBTQ identity and philanthropy are limited and group together the LGBTQ community as one group. For example, Garvey and Drezner (2013a) refer to "LGBTQ alumni" throughout their study; however, it is not known how many alumni identify as lesbian, gay, bisexual, transgender, and queer independently. Of note, in their limitations, they discussed that there were no transgender alumni interviewed and White gay males were overrepresented (Garvey \& Drezner, 2013a). The assumption that all LGBTQ alumni have similar experiences is problematic as their experiences can vary greatly (Sanlo, Rankin, \& Schoenberg, 2002) - especially the transgender population (Beemyn, 2005). Furthermore, Garvey and Drezner do not mention what it means to be "queer" or if any alumni actually identified as "queer" in their study (Garvey \& Drezner, 2013a). To avoid this broad scope, this study specifically pertains to gay male alumni. We also take into consideration race, which may further shape students' experiences on campus.

We paid close attention to how each alumnus described the campus climate at his alma mater. We took this approach because researchers have explored campus climate pertaining to racial minorities (Hurtado, Milem, Clayton-Pedersen, \& Allen, 1998; Reid, \& Radhakrishnan, 2003; Rankin \& Reason, 2005) and LGBTQ students (Evans \& Herriott, 2004). However, limited research takes into account that people are complex and have intersecting identities (Strayhorn, 2013). According to Sanlo et al (2002), "LGBT people on campus may be isolated from one another as LGBT people, but they may belong to one or more communities that have nothing to do with their sexual or gender identities" (p. 138-139). Gasman and Bowman (2013a) affirmed, "Unless historically White campuses are more inclusive and accepting — beyond just recruiting African Americans-Black alumni and African Americans won't give” (p. 22). We speculate the same idea may hold true for gay alumni. Therefore, this study focuses on the connection between a positive student experience and giving among gay alumni.

We begin this study by discussing alumni motivations to give. Then, we make the transition into giving motivations of non-traditional donors. We included alumni staff, campus climate, and LGBT students' experiences on campus in our discussion as well. Each category (e.g., campus climate, LGBT students' experiences) plays a role in predicting support from LGBT alumni. It is important to note that we use non-traditional donors and underrepresented donors 
interchangeably throughout this article to refer to alumni of color and LGBT alumni. Whereas, when we refer to traditional donors, we are referring to White, heterosexual males. We also use supporting and giving interchangeably, defined as financial donations and/or volunteering. Through this study, we hope to expose alumni offices to the potential of non-traditional donors, uplift underrepresented communities, and explore the motivations of giving among non-traditional alumni.

\subsection{Research Question}

What are the factors that motivate gay alumni to give back (defined as volunteering and/or financial donations) to their alma mater and do these factors vary by race among gay alumni? This research is important because philanthropy is a key to the prosperity of institutions of higher education. As college and university alumni become more diverse (Gasman \& Bowman, 2013b), it is increasingly important for institutions to know how to effectively engage alumni from an array of backgrounds.

\section{Literature Review}

United States census data predict by 2040 there will be more people of color than Whites in the United States (U.S. Census Bureau, 2012). With changing demographics of alumni, and students identifying with the LGBT community at a considerably younger age, colleges and universities must adapt if they want to engage non-traditional donors (Bilodeau \& Renn, 2005; Broido, 2004; Cabrales, 2013; Evans \& Herriott, 2004; Garvey \& Drezner, 2013b; Gasman, 2008; Gasman \& Bowman, 2013b; McClellan \& Larimore, 2009; Renn, 2010; Scanlan \& Abrahams, 2002).

Historically oppressed alumni have been overlooked in the realm of philanthropic giving in institutions of higher education (Bowman, 2010; Cabrales, 2013; Carson, 2000; Garvey \& Drezner, 2013a; Gasman, 2008; Gasman \& Anderson-Thompkins, 2003; Gasman \& Bowman, 2011, 2012, 2013b; Scanlan \& Abrahams, 2002; Tsunoda, 2013). Underrepresented alumni are often disregarded, because they are seen as receivers as opposed to givers (Cabrales, 2013; Carson, 2000; Gasman \& Bowman, 2011). As fiscal hardships crush the higher education system, colleges and universities must explore all funding venues to ensure fiscal strength (Gasman \& Bowman, 2013b; Tom \& Elmer, 1994). If development officers act now another generation of underrepresented alumni can be engaged. This act is critical as "the future of philanthropic giving in higher education lies within an institution's young alumni and current students" (Drezner, 2009, p. 148).

\subsection{General Motivations to Give}

It is important to understand the fundamental motivations of individuals to give before we can understand ways to engage non-traditional donors. These motivations include relationships, trust, positive student experiences, financial aid packages, and the desire to maintain athletic and academic prestige.

\subsubsection{Relationships}

The most common theme in the literature is the pivotal role relationships play in fundraising (Lowenstein, 1997; Matheny, 1999; Morgan \& Hunt, 1994; Payton, Rosso, \& Tempel, 1991; Prince \& File, 1994; Waters, 2008, 2009; Worth, 2002). When defining relationships, we use Morgan and Hunt's (1994) definition, "we define relationship commitment as an exchange partner believing that an ongoing relationship with another is so important as to warrant maximum efforts at maintaining it" (p. 23). Often times, relationships are predictors of continual support (Waters, 2008), because fundraising is a personal process (Lowenstein, 1997). However, in order for any relationship to be successful, trust is essential (Lowenstein, 1997; Morgan \& Hunt, 1994).

\subsubsection{Trust}

Trust exists when "one party has confidence in a partner's reliability and integrity" (Morgan \& Hunt, 1994, p. 23). Because "trust tends to build up gradually through cumulative commitment to a relationship (McDonald, 1981, p. 834), it is essential that development staff cultivate personal relationships with donors (Lowenstein, 1997). Lowenstein (1997) said, "Major donors tend to give to people, not to programs - that is, they give to people in whom they have trust and confidence" (p. 6).

\subsubsection{Student Experiences}

A positive college experience is directly influenced by a student's involvement on campus (Clotfelter, 2003). Given that student involvement (e.g., athletics, clubs and organizations, and/or Greek life) is a predictor of alumni support (Dugan, Mullin, \& Siegfried, 2000; Holmes, 2009; Monks, 2003), colleges and universities must offer a wide range of activities and encourage student involvement. Clotfelter (2003) found alumni who attended liberal arts colleges gave more than alumni who attended larger universities. Clotfelter's findings align with Astin (1999) who found, "students attending private liberal arts colleges are more satisfied with the faculty, the quality of teaching, the general education program, and are more likely to view the institution as student-oriented," (p. 83), compared to all other types of institutions. Astin 
(1999) also found students attending liberal arts colleges are more likely to "trust" the administration and hold an elected student office position (i.e., student involvement). These components are significant as both trust (Lowenstein, 1997) and student involvement are important predictors of alumni support (Holmes, 2009; Monks, 2003),

\subsubsection{Financial Aid}

Smaller bodies of scholarship mention motivations of alumni to give back based on the financial aid packages they received as students. Dugan et al. (2000) hypothesized financial aid was part of students' satisfaction-influencing alumni support. They found need-based scholarships increased the likelihood of giving by 12 percent, whereas need-based loans decreased the likelihood of giving by 13 percent. Thus, although there is a clear difference between loans and scholarships, financial aid does play a role predicting alumni support (Dugan et al., 2000).

\subsubsection{Athletic and Academic Prestige}

Holmes (2009) found athletic prestige and academic prestige both influenced giving at Middlebury College. With regard to athletic prestige, giving increased by $4 \%$ when the men's hockey team had a ten-percentage point lead; he linked this increase to "warm glow" (p. 27). Giving also increased by $1.4 \%$ when Middlebury College fell by one place in college rankings; he hypothesized this increase was due to alumni wanting to preserve the academic prestige of the College (Holmes, 2009). Despite these findings, Holmes only explored one liberal arts college with a strong hockey team. These findings would differ greatly when looking across institution types (e.g., universities with large football teams).

We know traditional donors give because of relationships, trust, a positive student experience, financial aid packages, and a desire to maintain athletic and academic prestige. However, much less is understood about why non-traditional donors give and if their motivations are different than their White, heterosexual counterparts.

\subsection{Giving Among Non-traditional Donors}

Although there are some commonalities among traditional and non-traditional donors (e.g., trust, relationships), non-traditional donors have different needs (Gasman \& Bowman, 2013b). Much of what we know regarding how to engage non-traditional alumni is focused on alumni of color (see Bowman, 2010; Cabrales, 2013; Gasman \& Bowman, 2013b). Gasman and Bowman (2013b) discussed how to engage African American, Asian American, Latino, and Native American alumni; however, they do not discuss how to engage LGBTQ donors. Furthermore, Gasman and Bowman (2013b) do not acknowledge other identities (e.g., sexual orientation, gender identity), which may further alter students' perceptions and experiences on campus. This identity potentially could change the best way to cultivate and solicit gay alumni of color, because students of color "have unique experiences due to their race and sexual orientation" (Patton, 2011, p. 28). Thus, racial minorities who are further marginalized based on sexual orientation, have different needs when compared to their heterosexual counterparts (Patton, 2011; Rankin \& Reason, 2005). Gasman and Bowman's (2013b) research is applicable to heterosexual alumni of color; however, we question its application to LGBTQ alumni of color.

Conversely, Garvey and Drezner (2013a) focus on LBGTQ alumni; however, no distinction is made between White LGBTQ alumni and LGBTQ alumni of color, who have different experiences due to multiple underrepresented identities (Patton, 2011). As Renn (2010) claimed, "there remains a dearth of research on transgender students and on LGBT students of color" (p. 135). Reaffirming Renn's claim, Patton (2011) called for more research specifically pertaining to LGBTQ students of color.

Within the literature for non-traditional donors, several themes emerged: uplift, relationships, a diverse alumni staff, and trust were among the factors that influenced giving. The process of acquiring engaged donors is twofold: It begins when students are enrolled and continues when they graduate. Thusly, another significant predictor of alumni support was a positive college experience. Two themes emerged as crucial predictors of a positive LGBT student experience in particular: Campus climate and LGBT support services.

\subsubsection{Uplift}

Much like the LGBTQ community (see Garvey \& Drezner, 2013b), alumni of color want to see their donations support people with which they identify (Cabrales, 2013; Gasman \& Anderson-Thompkins, 2003; Gasman \& Bowman, 2013b). In order to attract non-traditional donors, the institution should demonstrate that it is "committed to serving the donor's community" (Scanlan \& Abrahams, 2002, p. 203). Gasman and Anderson-Thompkins (2003) assert, "When asking for institutional support, it is important to show donors how their contribution will have an impact on the lives of African Americans" (p. 26). Among non-traditional donors, there is a commitment on behalf of the donor to "uplift" or advance their respective community. A commitment to uplift is a large predictor of support from underrepresented donors (Carson, 2008; Drezner, 2005; Garvey \& Drezner, 2013b; Gasman \& Bowman, 2013b; Scanlan \& Abrahams, 2002; Smith, Shue, Vest, \& Villarreal, 1999; Tsunoda, 2013). 


\subsubsection{Relationships}

Building off the framework outlined above, one commonality among traditional and non-traditional donors was the importance of relationships (Garvey \& Drezner, 2013a; Gasman \& Bowman, 2013b; Kaiser \& Dolan, 2013; Prince \& File, 1994; Waters, 2009). Gasman and Bowman (2013b) found, "having a specific contact in the fundraising and alumni relations offices with which African American alumni can become familiar is important" (p. 26). Thus, development staff should be diverse (e.g., with regard to race, sexual identity) so donor potential is maximized.

When engaging traditional donors, Waters (2009) discussed how fund-raisers acknowledge the fundamental importance of relationships with donors, yet struggle with how to foster and encourage relationships. In part, this disconnect may be related to fund-raisers using the same methods to solicit all donors. Based on the literature, non-traditional donors cannot be engaged the same way as traditional donors (Gasman \& Anderson-Thompkins, 2003; Gasman \& Bowman, 2013b; Garvey \& Drezner, 2013a, 2013b; Pettey, 2002). The solicitation and cultivation of donors must take into account the donor's social identities.

Furthermore, among all donors, Waters (2009) warned, "Nonprofit organizations cannot simply maintain relationships with their donors, but they should also work to restore relationships that may have been damaged based on past organizational behavior" (p. 330). Gasman and Anderson-Thompkins (2003) called for institutions to "rekindle" their relationships with Black college alumni who have become "estranged from the institution" (p. 40). In the realm of non-profit philanthropy, scholars, stress fund-raisers must not only maintain relationships, but also restore relationships, which may have been damaged due to distasteful experiences (Garvey \& Drezner, 2013b; Gasman \& Anderson-Thompkins, 2003; Waters, 2009).

\subsubsection{Alumni Staff}

We included alumni staff after relationships, because the two are connected: development staff members cultivate relationships with donors. Therefore, a diverse development staff is beneficial when engaging underrepresented donors (Garvey \& Drezner, 2013a; Gasman \& Anderson-Thompkins, 2003; Gasman \& Bowman, 2011). Gasman and Bowman (2011) call for development offices to hire fund-raisers of color to help ensure donors of color are effectively cultivated. Whereas, Garvey and Drezner (2013a) discussed the power of LGBTQ advancement staff to "rely on preexisting networks" and serve as "insiders, potentially increasing access to \{LGBTQ\} prospects" (p. 200). In addition to a diverse staff, all development officers should be culturally competent and understand the motives of non-traditional donors. This action ensures underrepresented donors feel valued, welcomed, and represented in the college or university (Bowman, 2010; Garvey \& Drezner, 2013a, 2013b; Gasman \& Bowman, 2013b).

\subsubsection{Trust}

Another key predictor of support from underrepresented alumni, like traditional alumni, is trust between the donor and alma mater (Garvey \& Drezner, 2013a; Gasman, 2008; Gasman \& Anderson-Thompkins, 2003; Gasman \& Bowman, 2013b). Gasman and Bowman (2013b) explained Black alumni often do not trust their alma mater based on previous experiences. These feelings of distrust often hinder support from underrepresented alumni. Although Gasman and Bowman (2013b) noted that alumni might not want to support their alma mater due to previous negative experiences with race, they fail to acknowledge that this mistrust may be in part due to sexual orientation. Given alumni were not asked about their sexual orientation, it is unknown if sexual orientation could have been another-perhaps less salient—reason for mistrust.

In order to increase and maintain trust, Waters (2009) discussed how essential it is to communicate with donors the initiatives their money is supporting; this communication establishes trust between the donor and organization. Gasman (2008) discussed how mistrust eventually would decrease with time; however, effectively communicating to Black donors what their money is supporting is essential as "they want to see the results of their giving" (p. 784). With regard to the LGBTQ community, Garvey and Drezner (2013b) called for advancement offices to involve LGBTQ people in the university to overcome "resentment from past experiences of discrimination" (p. 83) and regain trust.

Clearly, trust needs to be established for a successful exchange to happen between the donor and institution. Further recognizing the importance of trust among non-traditional donors, Garvey and Drezner (2013a) call for institutions to "heal those who have been affected and mend trusting relationships" (p. 212), with the LGBTQ community. When engaging underrepresented donors, trust is an unquestionable fundamental.

\subsection{LGBT Students' Experiences on Campus}

In this section, we examine LGBT students' experiences, emphasizing campus climate and LGBT support services. Campus climate is directly related to a student's college experience (Rankin, 2005), and a positive student experience is a predictor of giving among non-traditional alumni (Gasman \& Anderson-Thompkins, 2003; Gasman \& Bowman, 2013a). Therefore, it is important to understand LGBT students' experiences during college. 


\subsection{Campus Climate}

When we refer to campus climate, we are referring to Rankin's (2005) definition of campus climate. Rankin (2005) defined campus climate as the "cumulative attitudes, behaviors, and standard of employees and students concerning access for, inclusion of, and level of respect for individual and group needs, abilities, and potential" (p. 17).

The largest body of literature pertaining to campus climate looks at harassment and challenges LGBT students face on college campuses (Brown, Clarke, Gortmaker, \& Robinson-Keilig, 2004; D’ Augelli, 1992; Herek, 1993; Love, 1997; Norris, 1992; Rankin, 2003, 2005; Rhoades, 1994; Sanlo et al., 2002). D'Augelli (1992) found three fourths of lesbian and gay students experienced at least one form of harassment on campus. This hostile campus climate is problematic for students' safety (Dugan \& Yurman, 2011). More recently, Rankin (2005) provided a comprehensive overview of the various forms of harassment students still face on college and university campuses. She found during the previous year, more than one-third of LGBT undergraduate students experienced some form of harassment (e.g., spoken harassment, physical assaults, anti-LGBT graffiti). Rankin's findings (2005) suggest there is still much work to be done to improve campus climate for LGBT students. She explained, "Research from the past two decades demonstrates that college campuses have been inhospitable, and even hostile toward LGBT members" (p. 20). These findings are problematic for development officers who try to cultivate LGBT alumni, since a positive college experience is linked to giving (Clotfelter, 2003; Gasman \& Anderson-Thompkins, 2003; Gasman \& Bowman, 2013b), and a hostile campus climate shapes a student's college experience.

Rankin's (2005) findings also revealed that compared to their White LGBT counterparts, LGBT students of color were more likely to hide their sexual orientation or gender identity out of fear. This hidden identity can further hinder institutional support because students do not feel accepted or safe enough to reveal their true identity on campus. Therefore, it is imperative that research pertaining to giving among non-traditional donors takes into account donor's multiple identities. Despite the importance of intersecting identities, currently much research is homogenous. For example, there is ample research on Black males (see Harper, 2006; Kimbrough \& Harper, 2006), yet this research ignores sexual orientation. There is one study conducted by Patton (2011) that examined the campus climate for Black gay males at a Historically Black College.. Despite finding that Black colleges are "unsupportive" of Black gay men, Patton discussed how all but one student "established a firm sense of congruence with the campus despite instances where their sexual orientation was not validated or recognized" (Patton, 2011, p. 95). Of course, Patton's sample size of 6 students makes the findings not generalizable. Therefore, we wonder if the same holds true for Black gay males at predominately white institutions, as gay Black men battle being both a sexual and racial minority on campus. This status can further complicate and influence a student's sense of belonging with the college or university (Patton, 2011; Rankin, 2005)

Currently, there is no research pertaining to how campus climate influences giving among gay alumni of color. This research is important as students of color often have different experiences than their White counterparts (Patton, 2011; Rankin, 2005). Given a positive student experience is a predictor of alumni support among non-traditional donors (Clotfelter, 2003; Gasman \& Anderson-Thompkins, 2003; Gasman \& Bowman, 2013b), and campus climate is associated with a safe, welcoming atmosphere (Rankin, 2003, 2005). Anecdotally, campus climate shapes philanthropy from underrepresented donors. Therefore, it is essential colleges and universities assess their campus climate for underrepresented students, who one day will either support or not support the institution.

\subsection{LGBT Support Services}

Another common theme among the literature is LGBT support services (Beemyn, 2002; Roper, 2009; Sanlo et al., 2002). One initiative adopted by many institutions is to create an LGBT center on campus (Fine, 2012). Despite this initiative, Sanlo et al. (2002) found the least likely reason for establishing an LGBT center was to enhance diversity and foster a "welcoming campus climate" (p. 14). Rather, centers evolved out of harassment incidents (Sanlo et al., 2002), and were established to combat instances of intolerance against the LGBT community on campuses in hopes of improving the campus climate (Sanlo et al., 2002).

It is worth noting there is no clear consensus on the connection between LGBT centers and an institution's endowment. Beemyn (2002) found institutions with large endowments are more likely to have an LGBT center. However, Fine (2012) found endowment was not a statistically significant predictor in her model for predicting LGBT centers on college and university campuses.

Other scholars (e.g., Evans \& Broido, 1999; Renn, 2007; Renn \& Bilodeau, 2005; Rhoads, 1997, 1998) have studied LGBT student leadership on college campuses. LGBT student leadership heavily influenced several students' career aspirations and helped students understand themselves (Renn, 2007). Given that university environments play a role in the development of LGBT students (Evans \& Broido, 1999; Evans \& Herriott, 2004; Renn \& Bilodeau, 2005; Rhoads, 1994), institutions of higher education must adequately support LGBT students. If institutions adequately support 
LGBT students, they will be more inclined to give back as alumni, because it directly shapes their college experience (Gasman \& Anderson-Thompkins, 2003; Gasman \& Bowman, 2013a). The college experience is a predictor of support among underrepresented alumni.

Another predictor of support is emotional attachment to one's alma mater (Drezner, 2009; Garvey \& Drezner, 2013a; Gasman \& Anderson-Thompkins, 2003). Considering "emotional attachment to a graduate's college or university is indicative of positive experiences and relationships" (Garvey \& Drezner, 2013a, p. 201), colleges and universities must better understand and support LGBT students.

\subsection{Summary of Motivations to Give}

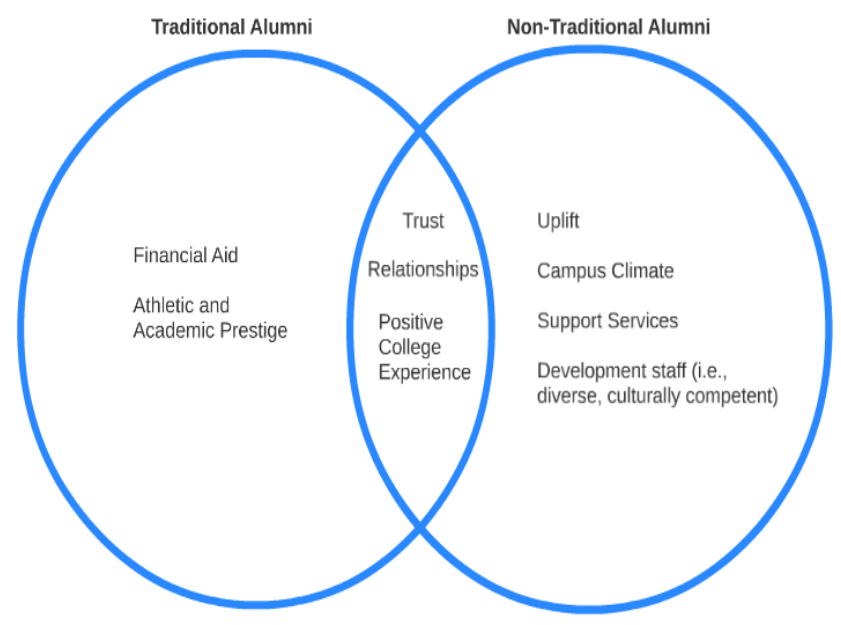

\section{Methodology}

In order to answer our research question -- What are the factors that motivate gay alumni to give back (defined as volunteering and/or financial donations) to their alma mater and do these factors vary by race within the gay alumni population? - we conducted a qualitative study, which examined the experiences and perceptions of 20 gay male alumni at one predominately White institution. We examined how their race and sexual orientation influenced their experiences on campus and consequently engagement and giving to their alma mater as alumni. We interviewed an equal number of gay White alumni and gay alumni of color to gauge if race/ethnicity also influenced giving motivations.

We included volunteering in our definition of philanthropy as "philanthropy is being expressed in communities of color in a multiple of ways that are not always recognized, counted, or valued as philanthropy" (W.K. Kellogg Foundation, 2012 , p. 12). This broad definition ensures alumni of color are given credit for their valuable time, which is an important component of philanthropy (W.K. Kellogg Foundation, 2012).

For this study, we used snowball sampling. We initially contacted 16 gay alumni through email and Facebook and asked if they would be willing to participate in a qualitative study pertaining to alumni giving. We received 12 yes responses. At the end of the interview, alumni were asked if they knew any other gay alumni who would be willing to participate in the study. Almost every alumnus provided us with 2 to 6 names and emails of gay alumni, who we then contacted via email.

After we collected the names and emails of other alumni from those who we interviewed, we noticed gay White alumni were overrepresented. Therefore, after the first ten interviews were conducted with White gay males, we only contacted gay alumni of color. One alumnus of color provided us with a list of gay alumni of color he knew. We progressed down the list until we received 8 yes responses from gay alumni of color. It was much harder to persuade gay alumni of color to participate because they felt their identity would be revealed. Our experience aligns with Meyer's (1993) who found that "individuals who do not accept themselves and who have not successfully 'come out' are less likely to participate in studies of gay men than individuals who accept themselves (Meyers, 1995, p. 40). Approximately 18 gay alumni of color were contacted, before 8 agreed to the interview. Alumni of color were much more concerned about identity protection and pseudonyms being assigned to them. These concerns align with Rankin's (2005) findings, "that LGBT people of color were more likely than white LGBT people to conceal their sexual orientation" (p. 19). 


\subsection{Site Description}

Northeast College (pseudonym) is a public, mid-sized master's granting college located in a suburban area; the college was founded in the late $20^{\text {th }}$ century with state funding. Northeast Public College serves both undergraduate and graduate students with a total student population of 8,458 students. Northeast College is a predominately white institution with $25 \%$ students of color (i.e., approximately $7 \%$ Black, $8 \%$ Hispanic, $5 \%$ Asian/Pacific Islander, $3 \%$ Native American, and other). The College has an estimated 44,000 living alumni and an endowment of almost \$19.5 million. The Unified Black Student Society (UBSS) and Pride Alliance (LGBT student organization) are among some of the most active student organizations on campus. The institution prides itself on diversity and is described by students as "a very open, liberal place." It is important to note, in the following sections, we use Northeast College as a pseudonym for the College.

\subsection{Participants}

Some alumni were fully open about their sexuality and others were not out. The study included 10 White alumni, 6 Black alumni, 3 Hispanic alumni, and 1 alumnus who identified as both Hispanic and White. All alumni graduated from Northeast College within the last six years; a majority of participants graduated within the last 2 years. Alumni were asked to self-identify their race/ethnicity and sexual orientation. Each alumnus was assigned a pseudonym. Data collection consisted of phone interviews, which lasted approximately 30 minutes each. Once the 20 interviews were complete, we transcribed the interviews. Open coding was used to look for common themes among alumni.

\section{Limitations}

Given that little scholarship exists on LGBTQ philanthropy we relied heavily on the scholarship around engaging alumni of color (e.g., Gasman \& Bowman, 2013b) for this study. It is also important to mention that this study cannot be generalized to other institutions. Our research took place at one public predominately white institution in the Northeast. If this study was conducted in a different, perhaps more conservative state, responses may have been very different.

Although we refer to alumni of color throughout this study, Asian Americans and Pacific Islanders and Native Americans were not represented. Rather, all alumni of color were Black or Hispanic. We also did not explicitly ask students of color if their race further complicated their experiences. We relied on them to share with us what it was like being a gay student of color.

Finally, people are complex and have multiple identities. We were very strategic in interviewing 10 alumni of color and 10 White alumni from the same institution. We also took into consideration their racial and sexual identities; however, we did not specifically examine other identities such as socio-economic status and disability. If an alumnus shared with us other identities such as a disability (see Max) or socio-economic status (see Bruce) we did make note of it; however, we did not further explore what it meant to be a White gay male with Asperger's Syndrome (see Max) or a poor Black, gay, male (see Bruce). We also did not ask alumni about their religion, which can also have a significant impact - especially on the LGBT population. These identities could have further influenced their experiences on campus.

\section{Researcher's Identity, Experiences, and Motivations}

\subsection{Lead Author}

My research is heavily influenced by my undergraduate experience as the first openly gay Student Senate president (i.e., Student Government Association president) of a college in New Jersey. During my tenure, I charged the Student Senate with tackling the presence of Chick-fil-A on our college campus. Chick-fil-A was acting as a catalyst for increased instances of intolerance to emerge on the campus, due to its history of funding anti-gay organizations. After I witnessed instances of intolerance and listened to my LGBT constituents, I created a survey, which polled students on their perceptions of Chick-fil-A on campus. Despite the franchise's anti-gay stance, the survey results revealed a majority of students wanted the franchise to stay. In a town hall meeting, I announced it was unfair to leave the rights of the minority up to the majority. Thus, the Student Senate would vote on whether or not Chick-fil-A would stay on campus.

On the day of the vote, the Student Senate was bombarded with students on both sides: each side wanted their voice heard before the vote. One student approached the podium and read the following:

I came to the college because I felt like it was my home; I no longer feel this way. Since issues with Chick-fil-A, I do not feel safe or supported on campus. I feel like the institution is not acknowledging my concerns with the franchise. When I graduate from the college, I will not give money, and I will not recommend this institution to my friends. Senators, please make the right decision.

As I reflected on the comments made by the second-year lesbian student, questions crystallized: Does a positive student 
experience and safe campus climate influence giving from LGBT alumni? Do LGBT alumni have different needs than their heterosexual counterparts? Why?

Ultimately, the Student Senate voted 14-10-3 to remove the franchise. This vote led to a letter of resolution, which asked the college to break ties with the franchise. This resolution enabled me to work with the college's senior leadership and Dan Cathy - Chief Operations Officer of Chick-fil-A franchises. Through a series of conference calls I explained to Cathy that Chick-fil-A had become a label of hate at the college and at institutions of higher education across the country.

As I spoke with Cathy, I gained a broad understanding of the franchise's ties to the Southern Baptist religion and the history of the Cathy family. On the flip side, I exposed Cathy to issues that were happening on college campuses across the country because of Chick-fil-A's donation practices. Ultimately, Cathy recognized the detrimental impact his donation practices were having on LGBTs at the college and across the country. Thus, he told us the franchise would no longer be funding the organizations the Student Senate and I were most concerned with. Cathy's actions prompted me to void the resolution to remove Chick-fil-A from the college's campus; however, my questions concerning LGBT alumni giving remained unanswered.

\subsection{Second Author}

I am a professor of higher education focused on issues of diversity as well as fundraising and philanthropy in communities of color. Due to my interests, students wanting to explore these issues gravitate toward me. I try to provide a supportive and nurturing environment to foster exploration in this area because I believe that all students have the right to a positive campus climate. I also think it is important that colleges and universities embrace both their alumni of color and their LGBTQ alumni. It is for this reason that I support and collaborate with students interested in expanding the research base in this area.

\section{Findings and Discussion}

\subsection{LGBT Identity and Philanthropy}

Unquestionably, the gay identity of alumni influenced their giving; however, identity was not the sole factor in determining support. Alumni were asked, "Do you think your experiences as a member of the LGBT community at \{Northeast College\} shape your decision whether to give back to the institution? If so, how?" Out of the 20 alumni, 13 answered no, 6 answered yes, and 1 alumnus changed his initial response mid-way. These findings align with Drezner and Garvey (2013b) who noted, "when directly asked if their sexual or gender minority identity affected their philanthropic giving towards their alma mater...most participants simply said, "no"” (p. 78). Garvey and Drezner (2012) further explained, "when delving into their philanthropic priorities and reasons for supporting or not supporting their alma mater, many of their philanthropic priorities involved supporting LGBTQ communities" (p. 78). We found the same in our participants.

Subsequent to this question on LGBT identity and giving, we asked alumni, "What else about your undergraduate experience has shaped your decision to support or not support the College?" The 13 alumni, who responded that their LGBT identity does not influence their decision to give back, shared their experiences about why they give back. Generally, part of their reasons linked to their LGBT identity; however, these reasons were often "unconscious" (Garvey \& Drezner, 2013b, p. 78). For example, Andres wants to support the institution; he believes his decision is completely unrelated to his LGBT identity. In his words, he wants to support Northeast College because: "It was a very comfortable environment; there was a lot of acceptance there. They treat everyone equally-especially when it comes to volunteering and giving money, it does not matter who you are, you are still important at \{Northeast College\}." Although Andres did not mention his LGBT identity specifically, an environment of acceptance was important to him.

The alumnus who changed his response half way through the question on LGBT identity and giving appeared to become more "conscious" about how his overall experience was shaped by the positive experiences he faced as a gay male on campus. According to this alumnus:

I wouldn't say it was being part of the LGBT community, I think it was more of my overall experience there that I was satisfied with that makes me want to give back. Well, I guess also being part of that community-where at other schools that community may feel singled out or they may not have different things available than \{Northeast College\} did. Then, I believe I could say that maybe my decision would be different.

Like Jason, other alumni may not have thought in depth about the connection between their philanthropy and gay identity until asked during our interviews.

Conversely, 6 alumni did in fact believe their LGBT identity influenced their giving. Noah described how his LGBT identity shapes his decision to give: "If it was a school that was against someone like me, or had certain policies, or a 
lack of support, I could see myself not giving back because of that." Much like Garvey and Drezner's findings (2013b), gay alumni in this study wanted to know their alma mater was being inclusive of the LGBT community:

I would not be willing to support an organization that has non-inclusive policies. Knowing they are an open and welcoming organization is a selling point, if they were a starch bible beltin' college that wanted the gays to go to hell — where they belong - I would not be inclined to open my wallet... I can guarantee there are a lot of Colleges that would not fly the rainbow flag so I give the College a lot of credit for that initiative (Noah).

Other LGBT alumni are specifically looking for the institution to host initiatives around LGBT awareness, before they will give back, noting, "If the institution was doing nothing to incorporate LGBT diversity, I would not give back to it; in fact, I would have actually transferred out of the school if that was the case."

All Black alumni said their LGBT identity did not influence their giving and all but one Hispanic alumnus responded similarly. Among various other factors, one theme emerged among the Black gay males who want to give back to the institution. They discussed being invested in the college and that the institution provided them with the "opportunity to an education" and a "chance to succeed"; therefore, they felt almost "obligated" to invest in someone younger. Nelson summed up Black gay males' responses: "When you are invested in I feel like you should invest in someone else; it is almost like an obligation." The same theme was not seen among White gay males' interviews. The Black gay men who felt "obligated" to help others in their community because they were helped, aligns closely with the literature pertaining to why Black alumni give back (e.g., Gasman, 2008).

Among gay alumni who were willing to support the institution the most common factor influencing support was an "overall positive student experience." Across the board, regardless of race, alumni connected an "overall positive student experience" with a positive, safe atmosphere; phenomenal faculty and staff who cared about them; many diverse events on campus; and a quality education.

Many alumni also mentioned that seeing LGBT people in leadership roles helped them on campus and created a more welcoming environment, which increased their overall satisfaction with Northeast College. According to Max, "Being a gay male at \{Northeast College\} was different; everyone was ok with it but I did have a few altercations.... However, Larry (pseudonym), the Director of Student Development—who was also gay—really helped me. Anytime I had a problem \{due to my sexual identity\} he would take care of it." Another alumnus explained how out faculty and staff helped ease his comfort with his sexual orientation: "Having people who in positions of authority who are also open about who they are really made me feel like I could be whoever I wanted to be and not be harassed." This finding aligns with Gasman and Bowman (2013b) who discussed the importance of underrepresented alumni seeing people like themselves in leadership roles at their alma mater before they will give back. Furthermore, Garvey and Drezner (2013b) found "diverse donors express an importance in seeing organization leadership that is inclusive of people with similar identities and beliefs to their own" (p. 75).

\subsection{Negative Experiences and Non-Giving}

Out of the 20 alumni, 6 said they would not support the institution. These alumni faced negative experiences on campus, because of their sexual orientation. Several of these negative experiences occurred throughout the College's residence halls. According to Carl, "I felt inhibited being gay...I remember I was at a party \{on campus\}, and there were these people from upstairs there too and they were like oh, yeah if there was a gay guy living with me I would be like get him away from me. But, I just sat there and didn't say anything...things like that."

Negative experiences unrelated to residential life also emerged from two alumni who are unwilling to support the institution today. Chris described his experiences:

When I was running the organization \{Pride Alliance\} I felt like we were a second-class organization and that always put a bad taste in my mouth, as that is how we were thought of. And it was only when my senior year came around that we began to be viewed differently and that was because certain students became more involved with school policies and politics and with what was going on - that is why the LGBT group actually began to have a stance and a say, but my previous years were bad.

Other alumni who were active members of the Pride Alliance described similar feelings as Chris. One alumnus described his encounter with a fraternity at a club fair. He was trying to recruit members to join the Pride Alliance when a fraternity walked by the table and made "gay jokes." In Carl's words, "I remember there was an incident at one of the club days and one of the faculty or staff members was being distant. She was being very stand offish; she didn't do anything even though she heard what the frat boys said."

It is also important to note that other themes — not related to LGBT identity — emerged as other key factors deterring alumni support. The lack of student empowerment and voice and a rapidly changing institution were important themes that surfaced. Chris shared the same feelings as a few other alumni who stated they would not support the institution: 
When I started 6 years ago, the institution was very different. There was no campus center, G-Wing still existed. It was a small school, everyone knew each other and there was a strong sense of community and I feel like over the years the politics within the administration changed what \{Northeast College\} was all about and it was not the College I fell in love with when I started going there and that made me upset. It was not a school I believed in anymore. It would have been nice to have more of a voice and more weight with the voice I did have. I made a lot of changes for the LGBT community and for admissions - because that's where the ambassadors worked. If they took the students' opinions more seriously, I probably would contribute back.

Other alumni expressed frustration with constant talk around diversity but LGBT students being ignored. Both current students and alumni look to see the institution is committed to serving their community. According to Tommy,

They do not go out of their way to incorporate the LGBT community into diversity, I know their main thing recently has been diversity...but as an entity alone, I do not think they are doing a fantastic job with LGBTs, maybe diversity is the first step for them to expand into the other categories that constitute diversity such as sexual orientation but they do not realize that yet.

\subsection{Who Actually Gave Back?}

We also asked alumni if they supported Northeast College since graduating. Out of all alumni, 3 alumni have already given back to Northeast College. All alumni who gave back were White gay males: Anthony, Chris, and Jake.

Anthony was the only alumnus who regularly donates to the College in small increments. His motivations to give back are heavily influenced by the positive experience he had on campus as a gay male. He noted:

They are welcoming. They were always there - they helped me a lot. I learned a lot through my experiences through my undergraduate studies and student involvement and there was never once a hesitation from an advisor or student or even a judgmental eye or words from them. They were always there to support me and a school like that should be recognized for their efforts of being open.

Ironically, Chris, who was very adamant about never giving back to the College, due to his negative experiences as a gay male, supported the institution. Although he did not give financially, he volunteered ample time to organize and host Aids Is a Drag, the drag show he founded when he was acting President of the Pride Alliance. In Chris's words, "I volunteered for the Pride Alliance, but I wouldn't for the College, the only reason I did it was so the organization could raise money for an organization that was not related to \{Northeast College\}, because I think they could use as much help as they can have. I wanted to raise money for a good cause."

Although Chris said he would never support the institution - he did. Chris supported an entity of the College that was meaningful to him. He had an "emotional connection" (Garvey \& Drezner, 2013a) to the Pride Alliance and the event he started while he was acting President of the Pride Alliance. It is also worth mentioning, all the proceeds from his drag show went to an LGBT AIDS Clinic (i.e., non-profit philanthropy).

In addition to volunteering to help at homecoming, Jake volunteered for the organization he co-founded when he was a student: the parent family association.

I volunteered for homecoming and for a couple of parent family association events. I went back and recruited new members for the association and helped facilitate events on campus as the co-founder for the organization. But, that is a subset of \{Northeast College\}, not the campus as a whole, but a very specific group of individuals (Jake).

Jake also explained how he wished there was a way to give directly to the LGBT community. Much like Garvey and Drezner's (2013b) findings, he wanted to "promote a welcoming and affirming community for current LGBTQ students" (p. 78). According to Jake,

I do think if there were an organization or office or department that was geared towards LGBT individuals there would be more motivation to say there is something going on campus that I think they are doing really good work and something I identify with...All these other universities have an LGBT office that caters to the needs of sexual minorities, something like that will really motivate me more to give.

Both Chris and Jake wanted to give "directly to benefit LGBTQ individuals at their alma mater" (Garvey \& Drezner, 2013b, p. 78). This practice is common among the LGBT community who want to uplift their community (Garvey \& Drezner, 2013b). Ironically, both Chris and Jake firmly said, "no" when asked if their LGBT identity influenced their giving.

The other 11 alumni, who said they want to give back, but have not yet done so, said their current student loan debt is deterring them. It is also important to reiterate that all alumni in this study graduated from the institution within the last 6 years; therefore, several alumni interviewed were enrolled in graduate school and others were still seeking employment. 


\subsection{Campus Climate and Philanthropy}

Four alumni of color described the campus as "lonely" and said they felt like "aliens" on campus. Whereas, the other six said they were "supported." Four White gay males felt "different" on campus and felt like "second class citizens." One common theme emerged among alumni who described the campus climate as "negative": they all described a negative experience they encountered due to their sexual orientation (e.g., micro-aggressions from professors, harassment), during their interview. All alumni were asked if they faced any challenges being a gay male at \{Northeast College\}; eight alumni were the only ones who described a negative experience they had related to their sexual orientation. Out of the eight alumni who experienced a "chilly campus climate," four said they would still support the institution. In contrast, the other half maintained they would never support Northeast College. Much like the African Americans interview by Gasman \& Anderson-Thompkins (2003), the gay men who would not give back among our participants, pointed to negative campus experiences.

The four alumni who had negative experiences, but will still support the institution are noteworthy. According to Tyler one of these alumni, "Although I felt lonely being a member of the LGBT community, at the end of the day I am happy to say I graduated from \{Northeast College\}. My teachers taught me so much, in that appreciation I would give back to the College." There experiences seem similar in terms of logic to the participants in Patton's (2011) research. She found that Black gay males "established a firm sense of congruence with the campus despite instances where their sexual orientation was not validated or recognized" (Patton, 2011, p. 95).

\subsection{Unique Needs of Gay Students of Color}

Gay students of color felt that the institution could do a lot more to support the LGBT population compared to their White gay male counterparts. These perceptions may stem in part from the fact that LGBT organization and White gay males dominated programs. According to Zach,

The issue at (Northeast College) is you go into an LGBT organization or program and the board is all White. You know it has to do with race. Everyone has the same background, everyone is on the same types of things, and likes the same things there is no variety. There is nothing different at the table. If you have a board that deals with LGBT then you need a board that represents each type of LGBT, that way each group has a voice in bringing in their respective community of people.

Another Black gay alumnus explained frustrations with gay students of color not being understood. In Bruce's words,

It's not White verses Black or Black verses Spanish you have to connect and engage not only with the White gay community but also connect with the Black gay community and the Latino gay community and bring them together as a whole, because their lifestyles are totally different so how you get their attention is in very different ways, does that make sense? Like, they need to distinguish the interest each specific group has and that is how they will bring gay students of color into LGBT life at \{Northeast College\}. Black and Latino gays will not go to an LGBT program that is geared towards something Caucasian gay men find appealing - it is not happening.

Zach, an alumnus, complained that not enough is being done around LGBT identity on the campus:

We needed to have a forum and create a mandatory course that deals with issues of sexuality. We have race courses but we don't have LGBT courses. And see, I don't think race is a factor in our lifestyle as much as it is in the straight lifestyle...At the end of the day, we are one community and if we tear each other down because of our race it would make it easier for someone who is straight to tear us both down.

Clearly, gay students of color had different perceptions and views compared to their White counterparts. It is important for colleges and universities to ensure LGBT outreach and programs are not solely geared towards the White gay male population.

\subsection{Overall Satisfaction}

Overall, only two of the 20 alumni felt Northeast College did an exceptional job supporting the LGBT population. One alumnus of color summed up a common perception among LGBT alumni:

I think they are starting to get more progressive mainly because of lobbying of students that was started by the Student Senate. But right now the administration just does not get it. Compared to other schools \{Northeast College \} really does not go out of their way to support LGBTs.

Almost all LGBT alumni felt the college did a "decent" job, but believe there is room for improvement.

\section{Recommendations}

\subsection{Recommendations for Future Research}

More research is needed on the unique experiences gay students of color face on college campuses and how these 
experiences influence giving. It is also important for future research to examine lesbians and bi-sexuals as their experiences on campus may be different from their gay counterparts. In terms of the transgender population, this population has very different needs compared to their LGB counterparts (Beemyn, 2005), and they face immense hurdles on college and university campuses (Beemyn, 2005).

Future research should examine the connection between sexual orientation and religion, socio-economic status, and/or disabilities. These identities influence a student's experience on campus and consequently giving or lack of giving as an alumnus or alumnae. For example, this influence was seen in Max (see Table 1.1), a gay White male with Asperger's Syndrome. Unquestionably, his disability highly influenced his experience on campus and further isolated him from both the LGBT community and his heterosexual counterparts.

\subsection{Recommendations for Practice}

It is essential that development offices keep demographics and data on underrepresented alumni. This collection of data is particularly important for LGBTQ students, since there is usually no self-identifier on admissions applications (Garvey \& Drezner, 2013b). To overcome this dilemma, Garvey and Drezner (2013b) recommend alumni offices partner with LGBTQ constituencies on campus (e.g., admissions, LGBTQ center) to collect data.

Given gay alumni are interested in supporting causes that uplift the LGBT community, it is fundamental development staff communicate to alumni how their donations will help uplift LGBT people. For this practice to work, development officers must be familiar with the specific culture of lesbian, gay, bisexual, and transgender alumni; they should also be familiar with other underrepresented identities (e.g., race, ethnicity).

On another note, a safe, welcoming campus climate and positive student experience are essential predictors of support. Therefore, given chief development officers often have direct access to the president, it is important for development officers to advocate for LGBT student services and support. All too often, colleges and universities rely on one chief diversity officer to support all underrepresented students. In order to have a "safe, welcoming campus climate" understanding and serving underrepresented students must be an institutional commitment.

\section{Conclusion}

This study reveals gay alumni give back because of positive experiences they had as students on campus. A positive campus climate, commitment to serving the LGBT population, and structural diversity (e.g., out LGBT faculty and staff) were main themes that emerged as to why gay alumni at Northeast College gave back or stated they will give back in the future. Equally as important were the ways gay alumni were solicited and kept engaged in the college. It is important for development officers to solicit and communicate with gay male alumni in a respectful and inclusive manner (e.g., advertisement with gay couples, thank you letters not addressed Mr. and Mrs.). Based on this study and previous work related to non-traditional donors, development officers should solicit gay alumni to support initiatives geared towards uplift of the LGBT community (e.g., LGBT center, LGBT student organization(s), scholarships for LGBT students).

Unquestionably, both sexual orientation and race played a role in the experiences and decisions of alumni to support or not support Northeast College. Consequently, it is important to understand the gay community is not one homogenous group. Black gay males in this study had different experiences and perceptions than their White gay counterparts. Therefore, colleges and universities must understand the specific culture of each population within the LGBT community to provide adequately support. 


\section{References}

Astin, A. W. (1999). How the liberal arts college affects students. Daedalus, 128(1), 77-100. Retrieved from http://www.jstor.org/stable/20027539

Beemyn, B. (2002). The development and administration of campus LGBT centers and offices. In R. Sanlo, S. Rankin, \& R. Schoenberg (Eds.), Our place on campus: Lesbian, gay, bisexual, transgender services and programs in higher education (pp. 25-32). Westport, CT: Greenwood Press.

Beemyn, B. G. (2005). Making campuses more inclusive of transgender students. Journal of Gay \& Lesbian Issues in Education, 3(1), 77-87. http://dx.doi.org/10.1300/J367v03n01_08

Bilodeau, B. L., \& Renn, K. A. (2005). Analysis of LGBT identity development models and implications for practice. New Direction for Student Services, 111, 25-39. http://dx.doi.org/10.1002/ss.171

Bowman, N. (2010). Cultivating future fundraisers of color at historically black colleges and universities. International Journal of Educational Advancement 10(3), 230-234. http://dx.doi.org/10.1057/ijea.2010.19

Broido, E. M. (2004). Understanding diversity in millennial students. In M. D. Coomes, \& R. DeBard, (Eds.), Serving the millennial generation, New Directions for student Services, No. 106 (pp. 7385). San Francisco, CA: JosseyBass.

Brown, R. D., Clarke, B., Gortmaker, V., \& Robinson-Keilig, R. (2004). Assessing the campus climate for gay, lesbian, bisexual, and transgender students using a multiple perspectives approach. Journal of College Student Development, 45(1), 8-26, http://dx.doi.org/10.1353/csd.2004.0003

Cabrales, J. A. (2013). An approach to engaging Latina/o alumni in giving initiatives. In N. D. Drezner (Ed.), Expanding the donor base in higher education: Engaging non-traditional donors (pp. 26-39). New York, NY: Routledge.

Carson, E. (2008). Black philanthropy's past, present, and future. In A. Walton, M. Gasman, (Eds.), Philanthropy, volunteerism, \& fundraising in higher education (pp. 774-777). Upper Saddle River, NJ: Pearson.

Carson, E. (2000). The new rules for engaging donors of color: Giving in the twenty-first century. In E. R. Tempel, \& D. F. Burlingame, (Eds.), Understanding the needs of donors: The supply side of charitable giving. New Directions for Philanthropic Fundraising, 29, (pp. 69-80). New York, NJ: Jossey-Bass.

Clotfelter, C. T. (2003). Alumni giving to elite private colleges and universities. Economics of Education Review, 22, 109-120. http://dx.doi.org/10.1016/S0272-7757(02)00028-6

D'Augelli, A. (1992). Lesbian and gay male undergraduates' experiences of harassment and fear on campus. Journal of Interpersonal Violence, 7(3), 383-395, http://dx.doi.org/10.1177/088626092007003007

Drezner, N. (2005). Thurgood Marshall: A study of philanthropy through racial uplift. In M. Gasman, K. Sedgwick (Eds.), Uplifting a people: African American philanthropy and Education (pp. 89-100). New York, NY: Peter Lang International Academic Publishers.

Drezner, N. (2011). Philanthropy and fundraising in American higher education. San Francisco, CA: Jossey-Bass.

Drezner, N. D. (2009). Why give?: Exploring social exchange and organization identification theories in the promotion of philanthropic behaviors of African-American millennials at private-HBCUs. International Journal of Educational Advancement, 9(3), 147-165. http://dx.doi.org/10.1057/ijea.2009.39

Drezner, N. D. (Ed.). (2013). Expanding the donor base in higher education: Engaging non-traditional donors. New York, NY: Routledge.

Dugan, K., Mullin, C. H., \& Siegfried, J. J. (2000). Undergraduate financial aid and subsequent giving behavior, WPEHE discussion paper series/ Williams College, Williams Project on the Economic of Higher Education, 57, http://www.nyu.edu/classes/jepsen/williamsstudy1100.pdf.

Evans, N. J., \& Herriott, T. D. (2004). Freshmen impressions: How investigating the campus climate for LGBT students affected four freshmen students. Journal of College Student Development, 45(3), 316-332, https://muse.jhu.edu/login?auth=0\&type=summary\&url=/journals/journal_of_college_student_development/v045/ 45.3evans.pdf

Evans, N. J., \& Broido, E. M. (1999). Coming out in college residence halls: Negotiation, meaning making, challenges, and support. Journal of College Study Development, 40, 658-668, http://multipleidentitieslgbtq.wiki.westga.edu/file/view/EvansBroido1999.pdf 
Fine, L. E. (2012). The context of creating space: Assessing the Likelihood of College LGBT center presence. Journal of College Student Development, 53(2), 285-299. http://dx.doi.org/10.1353/csd.2012.0017

Garvey, J. C., \& Drezner, N. D. (2013b). Alumni giving in the LGBTQ communities. In N. D. Drezner (Ed.), Expanding the donor base in higher education: Engaging non-traditional donors (pp. 74-86). New York, NY: Routledge.

Garvey, J. C., \& Drezner, N. D. (2013a). Advancement staff and alumni advocates: Cultivating LGBTQ alumni by promoting individual and community uplift. Journal of Diversity in Higher Education, 6(3), 199-218, http://dx.doi.org/10.1037/a0033452

Gasman, M., \& Anderson-Thompkins, S. (2003). Fund raising from black-college alumni: Successful strategies for supporting alma mater. Washington, DC: Council for the Advancement and Support of Education.

Gasman, M. (2007). Envisioning black colleges: A history of the united Negro college fund. Baltimore, MD: The Johns Hopkins University Press.

Gasman, M. (2008). An untapped resource: Bringing African Americans into the college and university giving process. In A. Walton, M. Gasman, (Eds.). Philanthropy, volunteerism, \& fundraising in higher education. Boston, MA: Pearson.

Gasman, M., \& Bowman, N. (2011). Cultivating and soliciting donors of color. Advancing philanthropy, (23), 54-56. Retrieved February 1, 2014, from http://www.ashe.ws/images/DonorsOfColor.pdf

Gasman, M., \& Bowman, N. (2012). A guide to fundraising at historically Black colleges and universities an all campus approach. New York, NY: Routledge.

Gasman, M., \& Bowman, N. (2013a). Engaging and soliciting African American alumni. In N. D. Drezner (Ed.), Expanding the donor base in higher education: Engaging non-traditional donors (pp. 15-25). New York, NY: Routledge.

Gasman, M., \& Bowman, N. (2013b). Engaging diverse college alumni: The essential guide to fundraising. New York, NY: Routledge.

Harper, S. R. (2006). Peer support for African American male college achievement: Beyond internalized racism and the burden of "acting White." Journal of African American Studies, 7(1), 47-56, $\mathrm{http}: / /$ repository.upenn.edu/cgi/viewcontent.cgi?article=1172\&context=gse_pubs

Herek, G. (1993). Documenting prejudice against lesbian and gay men: The Yale sexual orientation study. Journal of Homosexuality, 25, 15-30, http://dx.doi.org/10.1300/J082v25n04_02

Holmes, J. (2009). Prestige, charitable deductions and other determinants of alumni giving: Evidence from a highly selective liberal arts college. Economics of Education Review, 28(1), 18-28, http://dx.doi.org/10.1016/j.econedurev.2007.10.008

Hooks, B. (2004). We real cool: Black men and masculinity. New York, NY: Routledge.

Hurtado, S., Carter, D. F., \& Kardia, D. (1998). The climate for diversity: Key issues for institutional self study. In K. W. Bauer (Ed.), Campus climate: Understanding the critical components of today's colleges and universities. New Directions for Institutional Research, no. 98, (pp. 53-63). San Francisco, CA: Jossey-Bass.

Hurtado, S., Milem, J. F., Clayton-Pederson, A. R., \& Allen, W. R. (1998). Enhancing campus climates for racial/ethnic diversity: Educational policy and practice. The Review of Higher Educating 21(3), 279-302, https://muse.jhu.edu/login?auth=0\&type=summary\&url=/journals/review_of_higher_education/v021/21.3hurtado. html

Kaiser, S., \& Dolan, A. W. (2013). Women as a donor group to higher education. In N. D. Drezner (Ed.), Expanding the donor base in higher education: Engaging non-traditional donors (pp.61-73). New York, NY: Routledge.

Kimbrough, W. M., \& Harper, S. R. (2006). African American men at historically Black colleges and universities: Different environments, similar challenges. In M. Cuyjet \& Associates (Eds.), African American men in college (pp. 188-209). San Francisco: Jossey-Bass.

Kuh, G. D., Schuh, J. S., Whitt, E. J., Andreas, R. E., Lyons, J. W., Strange, C. C., Krehbiel, L. E., \& MacKay, K. A. (1991). Involving colleges: Successful approaches to fostering student learning and personal development outside the classroom. San Francisco, CA: Jossey-Bass.

Love, P. (1997). Contradicting and paradox: Attempting to change the culture of sexual orientation at a small, catholic college. Review of Higher Education,20(4), 381-398. http://dx.doi.org/10.1353/rhe.1997.0009

Lowenstein, R. L. (1997). Pragmatic fund-raising for college administrators and development officers. Gainesville, FL: 
The University Press of Florida.

Matheny, R. E. (1999). Major gifts: Solicitation strategies. Washington, DC: CASE Books.

McClellan, G. S., \& Larimore, J. (2009). The changing student population. In S. G. McGellan, \& J. Stringer, (Eds.), The handbook of student affairs administration (3rd ed., pp. 225-364). San Francisco, CA: Wiley.

McDonald, G. W. (1981). Structural Exchange and Marital Interaction. Journal of Marriage and the Family 43(4), 825-839, http://dx.doi.org/10.2307/351340

Meyer, I. H. (1995). Minority stress and mental health in gay men. Journal of Health and Social Behavior, 36(1), 38-56, Minority stress and mental health in gay men.

Monks, J. (2003). Patterns of giving to one's alma mater among young graduates from selective institutions. Economic of Education Review, 22(2), 121-130. http://dx.doi.org/10.1016/S0272-7757(02)00036-5

Morgan, R. M., \& Hunt, S. D. (1994). The commitment-trust theory of relationship marketing. Journal of Marketing, 58(3), 20-38. http://dx.doi.org/10.2307/1252308

Norris, W. P. (1992). Liberal attitudes and homophobic acts: The paradoxes of homosexual experience in a liberal institution. In K. M. Harbeck (Ed.), Coming out of the classroom closet: Gay and lesbian students, teachers and curricula (pp. 81-120). New York: Harrington Park Press.

Patton, L. D. (2011). Perspectives on identity, disclosure, and the campus environment among African American gay and bisexual men at one historically black college. Journal of College Student Development, 52(1), 77-100, http://dx.doi.org/10.1353/csd.2011.0001.

Payton, R., \& Tempel. (1991). Toward a philosophy of fund raising. In D. F. Burlingame, L.J. Hulse, (Eds.), Taking fund raising seriously (pp. 3-17) San Francisco, CA: Jossey-Bass.

Pettey, J. G. (2002). Cultivating diversity in fundraising. San Francisco, CA: Wiley \& Sons.

Prince, R. A., \& File, K. M. (1994). The seven faces of philanthropy: A new approach to cultivating major donors. San Francisco, CA: Jossey-Bass.

Rankin, S. (2003). Campus climate for gay, lesbian, bisexual, and transgender people: A national perspective. New York, NY: The Policy Institute of the National Gay and Lesbian Task Force.

Rankin, S. R. (2005). Campus climate for sexual minorities. New Direction for Student $\quad$ Services, $\quad 111 ， \quad$ 17-23, http://dx.doi.org/10.1002/ss.170

Rankin, S. R. (2006). LGBTQA students on campus: Is higher education making the Grade? Journal of Gay \& Lesbian Issues in Education 3(2/3), 111-117. http://dx.doi.org/10.1300/J367v03n02_11

Rankin, S. R., \& Reason, R. D. (2005). Differing perceptions: How students of color and white students perceive campus climate for underrepresented groups. Journal of College Student Development, 46(1), 43-61, http://www.brynmawr.edu/diversitycouncil/documents/Rankin.pdf

Reid, L. D., \& Radhakrishnan, P. (2003). Race matters: The relationship between race and general campus climate. Cultural Diversity and Ethnic Minority Psychology, 9(3), 263-275. http://dx.doi.org/10.1037/1099-9809.9.3.263

Renn, K. A., \& Bilodeau, B. (2005). Queer student leaders: An exploratory case study of identity development and LGBT student involvement at a midwestern research university. Journal of Gay \& Lesbian Issues in Education, 2(4), 49-71. http://dx.doi.org/10.1300/J367v02n04_04

Renn, K. A. (2007). LGBT student leaders and queer activists: Identities of lesbian, gay, bisexual, transgender, and queer identified college student leaders and activists. Journal of College Student Development, 48(3), 311-330, https://muse.jhu.edu/login?auth=0\&type=summary\&url=/journals/journal_of_college_student_development/v048/ 48.3renn.html

Renn, K. A. (2010). LGBT and queer research in higher education: The state and status of the field. Educational Researcher, 39(2), 132-141. http://dx.doi.org/10.3102/0013189X10362579

Rhoads, R. A. (1994). Coming out in college: The struggle for a queer identity. Westport, CT: Bergin and Garvey.

Rhoads, R. A. (1997). A subcultural study of gay and bisexual college males: Resisting developmental inclinations. Journal of Higher Education, 68, 460-482, http://www.jstor.org/stable/2960012?seq=1\#page_scan_tab_contents.

Rhoads, R. A. (1998). Freedom's web: Student activism in an age of cultural diversity. Baltimore, $\quad$ MD: Johns Hopkins University Press.

Roper, L. D. (2005). The role of senior student affairs officers in supporting LGBT students: Exploring the landscape of 
one's life. New Direction for Student Services, 111, 81-88, http://dx.doi.org/10.1002/ss.177

Sanlo, R., Rankin, S., \& Schoenberg, R. (Eds.). (2002). Our place on campus: lesbian, gay, bisexual, transgender services and programs in higher education Westport, CT: Greenwood Press.

Scanlan, J. B., \& Abrahams, J. (2002). Giving traditions of minority communities. In M.L. Worth (Ed.), New strategies for educational fund raising (pp. 197-205). Westport, CT: ACE.

Smith, B., Shue, S., Vest, J. L., \& Villarreal, J. (1999). Philanthropy in communities of color. Bloomington, IN: Indiana University Press.

Strayhorn, T. (2013). Living at the intersections: Social identities and Black collegians. New York: Information Age Publishing.

Tom, G., \& Elmer, L. (1994). Alumni willingness to give and contribution behavior. Journal of Services Marketing, 8(4) 57-62, http://dx.doi.org/10.1108/08876049410058442

Tsunoda, K. (2013). Chinese American philanthropy: Cultural contexts behind major gifts in higher education. In N. D. Drezner (Ed.), Expanding the donor base in higher education: Engaging non-traditional donors (pp. 40-57). New York, NY: Routledge.

United States Census Bureau. (2012). U.S. Census Bureau projections show a slower growing, older, more diverse nation a half century from now Retrieved January 22, 2014, from http://www.census.gov/newsroom/releases/archives/population/cb12-243.html

W. K. Kellogg Foundation. (2012). Cultures of giving: Energizing and expanding philanthropy by and for communities of color. Battle Creek, MI: W.K. Kellogg Foundation.

Waters, R. D. (2008). Applying relationship management theory to the fundraising process for individual donors. Journal of Communication Management, 12(1), 73-87. http://dx.doi.org/10.1108/13632540810854244

Waters, R. D. (2009). The importance of understanding donor preference and relationship cultivation strategies. Journal of Nonprofit \& Public Sector Marketing, 21, 327-346. http://dx.doi.org/10.1080/10495140802662523

Worth, M. J. (2002). New strategies for educational fund raising. Westport: Praeger Publishers.

\section{$(\mathrm{cc}) \mathrm{EY}$}

This work is licensed under a Creative Commons Attribution 3.0 License. 